\title{
The Role of Birds in English Literature and Poetry
}

\author{
Dr Roweena B D'couto
}

\begin{abstract}
Birds have been represented in various forms and symbols since time immemorial; man has always had a fascination towards nature especially in birds. When we look up at the sky, or at a tree, or even if we were to go to the highest of mountains or the driest of places there is always some superior living creature which is soaring higher than the human being. Birds might not match the human size yet, definitely have been a source of inspiration for mankind in various ways. This paper gives us an understanding into the references of birds being made as manifestations of the supreme; sometimes as superstitions and religious beliefs; stronger representation of power for countries and divine interpretations for human beings. It is brings out a comparative analysis of how doves and vultures have been referred in various contexts by various poets in English literature.
\end{abstract}

Keywords: Birds, Doves, Vultures, love and death.

Human beings and nature have always been interconnected and referred to, especially in the context of literature. If we were to imagine the world without mankind it would be so dull and void, on the contrary if human beings were to exist without nature, it would be an imbalance in the eco system, nature and man have been cordially existing ever since. Man has been using nature for different purposes, at times as a source for sustainable development, and as a means of survival, in fact, sometimes as one's own interest for knowledge and research and most of all an imagination which can lead and transform into a fascination.

Nature has influenced man's thought process both philosophically and psychologically in particular birds and animals. Birds have been studied as a part of the environment's eco system to mostly help in assessing the biodiversity of the earth. (Kratochwil), in his book has reflected on birds and hoe play an important part in the ecosystem that - theris a striking concordance of the bird's fauna with the vegetation and type of altitudinal belt".

Birds are also a source of inspiration to poets in order to understand and relate with nature in different aspects like feelings, signs, beliefs, and as messages, more often even used as messengers to communicate to far and distant places. Poets have used nature and its beauty to express their thoughts and feelings, Birds have always inspired poets in their qualities like their accuracy and stealth, their ability to hover around the highest snow capped mountains to the un endless seas and oceans.

Poetry is another source through which man has used birds as a way for expressing himself. Poets, writers, philosophers have been using different types of birds for expression. Interestingly, birds are also refereed to their exuberant and vibrant colours which reflect the brighter side of life. However, quiet contrary to the poet's descriptive details of birds, there is another way of analysing and differentiating one bird from another, in fact this has been illuminated upon by one poet.

(Nims. J.F) in his book stated the way one could be able to differentiate between birds and not generally use their reference in a common context - Ifne is interested in birds, one likes to be able to tell one from another-a cat bird from a mocking bird, a great racket tail drongo from a blue faced bobby",
Some of the basic to complex references about birds are seen in the works of poets who have used nature as a source to express their feelings and emotions sometimes as their main theme or as a subject for poetry and themes like describing the colour of the eye of the bird to very intimate details of the birds eating habits to the comparison of how humans look upon the bird for a number of reasons.

In the early nineteenth century, poets like Henry David Thoreau, Walt Whitman, Emily Dickinson, Sylvia Plath, Mary Oliver and a few others of the American literature, of the Romantic age, influenced other writers and poets about nature. They were able to use nature in the form of poetry to convey to others the efficacies of nature and its fauna and fauna

Some of the common birds which we generally come across are Doves, Eagles, Vultures, Sparrows and Ravens. Doves have often been referred to their colour and poise. In the Bible, the dove has been referred to as a symbol of the Holy Spirit descending upon Jesus Christ before being baptized. According to the bible in John Ch1: Verses: 32-34 New International Version (NIV), 32 Then John gave this testimony: - Isaw the Spirit come down from heaven as a dove and remain on him. ${ }^{33}$ And I myself did not know him, but the one who sent me to baptize with water told me, $=$ The man on whom you see the Spirit come down and remain is the one who will baptize with the Holy Spirit. ${ }^{34}$ I have seen and I testify that this is God's Chosen One."

When we take a look at some of the poetic references made we can see that the dove has been visualised as a symbol of love, in John Keats Poem, I had a dove, and the sweet dove died, the lines of which run through + had a dove, and the sweet dove died, And I have thought it died of grieving; $\mathrm{O}$ what could it grieve for? Its feet were tied" here the poem refers to the dove as a sign of a loved one who he is grieving for, perhaps the dove though often referred as a sign of peace is being referred to as love, the poet has tried to retain his love but could not succeed by doing so.

There is yet another feeling expressed by the poet David Krieger in his poem - Thedoves flew high" in this poem the poet expresses a feeling of peace, by letting off the doves, he wants others to understand and taste what freedom is, this is reflected in the lines of the poem as The President devoid of options ,chose peace. And the doves flew high" 


\section{International Journal of Science and Research (IJSR) \\ ISSN (Online): 2319-7064 \\ Index Copernicus Value (2013): 6.14 | Impact Factor (2015): 6.391}

In the poem of Edgar Allan Poe Sonnet-To Science", verse Science! True daughter of Old Time thou art! who alterest all things with thy peering eyes. Why preyest thou thus upon the poet's heart, Vulture, whose wings are dull realities?"

We should ponder on the reason as why were these differences made in birds especially if they were a source of inspiration to poets, if the dove was considered as a symbol of love purity and freedom then why is the vulture always referred to death and corpses, this perhaps can be best explained by the references of various poets using the vulture to give meaning to the consequences of our own actions. The poem $\vee$ ultures" by Chinua Achebe has beautifully brought out the feeling of love and togetherness between two vultures even when they were doing what all vultures normally do, some of the lines from the verses read like this In the greyness ,and drizzle of one despondent; dawn unstirred by harbingers, of sun break a vulture perching high on broken bones of a dead tree; nestled close to his mate his smooth bashed-in head, a pebble on a stem rooted in a dump of gross feathers, inclined affectionately to hers. Yesterday they picked the eyes of a swollen corpse in a water-logged trench and ate the things in its bowel.

In the poem The Vultures", by David Diop In that time, When civilization struck with insults; When holy water struck domesticated brows, The vultures built in the shadow of their claws, The bloody monument of the tutelary era ,In that time, Laughter gasped its last in the metallic hell of roads"

These lines have been rephrased by D.M. Aderibigbe Here the speaker took on the advent of slavery. Indeed, when the Europeans came to Africa, two of the major reasons which they used as pretexts for invading Africa were civilisation and Christianity, all of which Diop dealt with above".

(Dodiya), Đeath is regarded as the ultimate impurity, and the Parsis refuse to defile the earth with burial; instead, the body is exposed within a circular, unroofed tower known as the dakhma or the Tower of silence, where vultures devour it".

Many poets have used birds in their poetic references, but Wordsworth and Emily Dickenson have elaborately gone into intricate details of Nature and Birds, Emily Dickenson has observed birds to the extent of giving precise details of the bird's eating on worms in one of her famous poems she has quoted A Bird came down the Walk-He did not know I saw -He bit an Angleworm in halves, And ate the fellow, raw, And then he drank a Dew" here the poet has described in an explicit manner in which a bird is able to sustain itself from the pangs of hunger, not considering the threat which might await it or the kind of food it is feeding on,

These references made by different poets on birds goes beyond imagination it takes us in to a world of reality and how birds play a role in our attitude and approach towards life,

A few of the extracts from this paper highlights the qualities of birds, not only being used as symbols of superstitions or as mere messengers, but intensively reflecting on the feelings and imagination of how poets have used birds as a source of expression to express their feelings.

We need to reflect and compare ourselves with the perseverance which the birds possess and use as a day to day survival technique. Authors and Poets have used birds not only to bring out the qualities

\section{References}

[1] Author: -—ohn Keats - Complete poems" by Jack Stillinger, - - have a dove, and the sweet dove died", Belknap Harvard. $1^{\text {st }}$ edition, 1978, USA.

[2] Poem by Willaiam Words woth (1770-1850) PG 442

[3] - Be dwelt among the untrodden ways, She dwelt among the untrodden ways, Besides the springs of Dove,A maid whom there were none to praise, And very few to love".

[4] Kratochwil Anselm Biodiversity in Ecosystems: Principles and Case Studies of Different Complexity Levels,Springer Science \& Business Media, 30-Nov-2001

[5] 1.John Frederick Nims Second edition, Western Wind",An introduction to Poetry, Mc Graw-Hill publication.Printed in USA. Pg 20.

[6] — Brsi English Novel", Jaydipsinh Dodiya,Sarup and Son's,New Delhi, $1^{\text {st }}$ ed,2006

[7] D.M. Aderibigbe Stories of the invisible", The Blue Shift Journal, Issue 3, 2014, Retrieved from http://www.theblueshiftjournal.com. 